\title{
GENDER MAINSTREAMING IN THE HERMENEUTICS OF ISLAMIC FAMILY LAW
}

\author{
Athoillah Islamy \\ Lacturer at State Institute Islamic of Pekalongan \\ Email: Athoillahislamy@yahoo.co.id
}

\begin{abstract}
The problem of gender discrimination for women can occur in all spaces, both public and private spaces as well as in family life. This problem is not only caused by biased socio-cultural construction but can also be caused by biased interpretation of Islamic teachings. Even Though in the Qur'an and the Hadith itself highly upholds the equality of existence between men and women. There are two main objectives in this study. First, to find gender mainstreaming in the construction of Amina Wadud's al-Qur'an hermeneutic method. Second, to understand the application of Amina Wadud's hermeneutic method in interpreting verses about the pattern of gender relations in the family. This research is qualitative in the form of a literature study with a philosophical normative approach. The primary source used is an explanation of Amina Wadud's hermeneutic method in her book entitled Qur'an and Woman Rereading the Sacred Text from a Woman's Perspective. Meanwhile, secondary sources used are various relevant studies. There are two big conclusions of this research. First, Amina Wadud's hermeneutic alQur'an method considers three aspects as the basis for the interpretation of a text (verse), among others, the context in which the text was written and interpreted, the grammatical text, and the weltansanschaung. By considering these three aspects, Wadud tried to reinterpret a theological basis (verses of the Qur'an) related to the pattern of gender relations that have been interpreted by many classical commentators. Secondly, Wadud better understood the verses of gender relations in the family as functionalist relations. The functional relationship in question is the cooperative relationship over the distribution of rights and responsibilities between men and women based on their potential.
\end{abstract}

Problem diskriminasi jender pada kaum prempuan dapat terjadi dalam segala aspek, baik pada ruang publik maupun ruang privat seperti halnya dalam kehidupan keluarga. Problem ini tidak hanya disebabkan oleh konstruksi sosial yang bias, akan tetapi juga disebabkan oleh interpretasi yang bias terhadap ajaran Islam. Meskipun dalam al-Qur'an dan Hadis sendiri menjunjung tinggi kesetaraan eksistensi antara laki-laki dan prempuan. Terdapat dua tujuan utama dalam penelitian ini. Pertama, untuk menemukan gender mainstreaming dalam konstruksi metode hermeneutika al-Qur'an Amina Wadud. Kedua, untuk memahami aplikasi metode hermeneutika Amina Wadud dalam penafsiran ayat tentang pola relasi jender dalam keluarga. Penelitian ini merupakan penelitian kualitatif yang berupa 
kajian pustaka dengan pendekatan normatif filososfis. Sumber primer yang digunakan adalah penjelasan metode hermeneutika Amina Wadud dalam bukunya yang berjudul Qur'an and Woman Rereading the Sacred Text from a Woman's Perspective. Sementara itu, sumber sekunder yang digunakan adalah berbagai penelitian yang relevan. Ada dua kesimpulan besar penelitian ini. Pertama, metode hermeneutika al-Qur'an Amina Wadud mempertimbangkan tiga aspek sebagai dasar interpretasi terhadap sebuah teks (ayat), antara lain, konteks saat teks ditulis dan ditafsirkan, gramatikal teks, dan weltansanschaung. Mempertimbangkan ketiga aspek tersebut, Wadud mencoba menafsirkan kembali landasan teologis (ayat alQur'an) terkait pola relasi jender yang sudah banyak ditafsirkan oleh para mufasir klasik. Kedua, Wadud lebih memahami ayat-ayat relasi jender dalam keluarga sebagai hubungan fungsionalis. Hubungan fungsional yang dimaksud yakni hubungan kerja sama atas pembagian hak dan tanggung jawab masing-masing antara laki-laki dan perempuan berdasrakan potensi yang dimilikinya.

Keywords: Hermeneutics; Amina Wadud; Gender Relations; Family.

\section{INTRODUCTION}

Understanding religious texts in the context of modern life by placing the position of men and women proportionally, is not easy, that is, it requires a methodology and competence in interpretation of texts that can build a new interpretation paradigm that can reflect justice and gender equality. ${ }^{1}$ One method of interpretation that is starting to get a lot of attention among contemporary Islamic scholars is the hermeneutics method. In connection with the study of Islamic studies, hermeneutics has become a part of contemporary interpretation methods in the study of the interpretation of the Qur'an and Hadith.

Several factors have encouraged the use of the hermeneutic method as part of the development of contemporary methods in the interpretation of the Koran First, the existence of opinions about the Koran is a reflection and response to the social, cultural, economic and political conditions of the Arab society of Jahiliyah. Secondly, various methods in the classical ulumul Qur'an study are considered to be less relevant as a contextualization method in interpretation in the modern era.

Third, the classical interpretation methodology set is assumed to be too onesided to the ability of public reason tends to prioritize the meaning of the text by ignoring reality (context). ${ }^{2}$ Therefore, it is a necessity if the study of hermeneutics in Islamic studies is important and needs to be studied to develop and give birth to

${ }^{1}$ Athoillah Islamy, "Gender Mainstreaming dalam al-Qur'an dan Hadis serta Relevansinya Terhadap Epistemologi Hukum Islam,” Jurnal Hukum Islam, Vol. 15, No. 1 (2017), p. 193.

${ }^{2}$ Asep Setiawan, "Hermeneutika al-Qur'an Mazhab Yogya," Jurnal Studi Ilmu-Ilmu al-Qur'an dan Hadis, Vol. 17, No. 1(2016), p. 69-70. 
the paradigm and knowledge of Islamic studies that pivots on texts of Islamic teachings in the context of life that is constantly developing.

As a method of interpretation, the hermeneutical method does not only try to interpret the meaning of the text textually but also explores its content by considering various aspects of the text, both the author, the reader and the conditions surrounding the text itself. The use of the hermeneutic method in the study of the interpretation of the Qur'an has been carried out by contemporary Muslim scholars, both in the West and East. Although these conditions have experienced pros and cons responses from Muslim scholars and scholars themselves. But amid pros and cons, the method which is part of this philosophical study continues to experience significant development at the hands of contemporary Muslim hermeneutics. One such contemporary scholar is Amina Wadud, an Islamic scholar from a woman who tries to criticize various Islamic legal doctrines which she considers to be gender biased. Where Wadud's critical attitude is manifested by reinterpreting the verses of the Qur'an with the hermeneutical method it offers. Therefore, in this paper, the author will explain an explanation of the hermeneutical method of interpreting verses of the Qur'an according to Amina Wadud.

\section{DISCUSSION}

\section{A. Amina Wadud, An Intellectual Diaspora and Her Works}

The full name of Amina Wadud, namely Amina Wadud Muhsin. He was born in Bethesda, Maryland, the United States on September 25, 1952. His father was a Methodist and his mother was a descendant of Berber, Arabic, and African slaves. Wadud decided to become a Muslim in 1972. Wadud was a widow who was blessed with five children (two boys and three girls). Wadud's academic journey in college began in the field of education at the University of Pennsylvania. Wadud earned a bachelor's degree (B.S) in 1975. Then Wadud continued his postgraduate studies by earning a master's degree (M.A) in 1982 in the field of Near Eastern Studies at The University of Michigan. Still, at the same university, Wadud also won a Doctorate (Ph.D.) in 1988 in the field of Islamic Studies and Arabic. Since completing his studies from the University of Pennsylvania, Wadud has been a lecturer in the English department at the Qar Yunis University College of Education, Libya. After returning from Libya, Wadud taught at the Islamic Community Center School in Philadelphia, United States. Aside from being a feminist, Wadud is also a Professor at Commonwealth University, Richmond Virginia. Where in 1988, Wadud also obtained a doctorate in Arabic and Islamic studies at Michigan University. Wadud also studied Islamic philosophy at al-Azhar 
and studied the interpretation of the Qur'an at Cairo University, Egypt. Besides Arabic, Wadud is also proficient in English, Turkish, Spanish, French, and German. From his expertise in various languages, Wadud received many offers to be a guest lecturer at various universities, including Harvard Divinity School (19971998), International Islamic Malaysia (1990-1991), Michigan University, American University in Cairo (1981- 1982) and Pennsylvania University (1970-1975). In 1999, Wadud was a consultant workshop in Islamic and gender studies organized by the Maldivian Women's Ministry and the United Nations. ${ }^{3}$

There are two Wadud's writings in book form, namely the Qur'an and Woman: Rereading the Sacred Text from a Woman's Perspective published in 1999 and Inside the Gender Jihad: Women's Reform in Islam published in 2006. A book entitled "Qur'an and Woman' is Wadud's first most popular work. Wadud's writings are mostly in the form of scientific journal articles. Some of the journal's articles include "Muslim Women as Minority", Journal of Muslim Minority Affairs, London (1989); "The Dynamics of Male-Female Relationship In Islam", Malaysian Law News (July 1990); "Women in Islam: Masculine and Feminine Dynamics in Islamic Liturgy, Faith, Pragmatics and Development" (Hong Kong, 1991); "Understanding the Implicit Qur'anic Parameters to the Role of Women in the Modern Context" (1992); "Islam: A Rising Responses of Black Spiritual Activism" (1994) and "Sisters in Islam: Effective against All Odds, in Doug Newsom's Silent Voices" (1995). ${ }^{4}$

\section{B. Gender Relations in the Qur'anic Perspective}

The word "gender" comes from English is gender. In etymology (language), gender has a gendered meaning. ${ }^{5}$ Meanwhile, in terminology, there are various definitions. According to Kamla Bashin, as quoted by Rusli, Kamla distinguishes between gender and sex (sex). According to him, sex is a biological thing. While gender is the result of human creation which can change from time to time, from one culture to another related to the responsibilities, roles, patterns of behavior, and others between men and women. ${ }^{6}$ Corsini also defines gender as being related to masculinity and femininity created based on socio-cultural conditions. ${ }^{7}$

\footnotetext{
${ }^{3}$ https://en.wikipedia.org/wiki/Amina_Wadud.

${ }^{4}$ Mutrofin, "Kesetaraan Gender dalam Pandangan Amina Wadud dan Riffat Hassan,"Teosofi, Vol.3, No. 1 (2013), p. 238-240.

5Jhon M. Echols, Hasan Shadily, Kamus Inggris Indonesia (Jakarta: Gramedia, 1983), 265. 1999), 1st Edition, p. 34-35.

${ }^{6}$ Rusli, "Isu-Isu Gender Dalam BingkaiI Metodologi Studi Islam," Musawa, Vol.4 No.1 (2012), p. 26.

${ }^{7}$ Mohd Anuar Ramli, " Gender Analysis In Islamic Jurisprudence," Journal Of Figh, No. 9 ; (2012), p. 141-142.
} 
Furthermore, Musdah Mulia defines gender as a set of roles, functions, and responsibilities inherent in men and women based on certain cultural constructions. ${ }^{8}$ Nasaruddin Umar defines gender as a concept used to differentiate between men and women based on socio-cultural construction, not on biological differences. ${ }^{9}$ From this, it can be understood that gender is a form of division of tasks, rights, responsibilities, and behaviors inherent to men and women that are dynamic, local and temporal following the changes and social and cultural developments that exist. While sex is a matter that is related to gender and its biological functions.

Furthermore, in the gender discourse, the term feminist is known. Etymologically the word "feminism" comes from the Latin "femina" which in English becomes "feminine" meaning to have characteristics as women. Meanwhile, in terminology, feminism, namely awareness of discrimination, injustice, and subordination experienced by women. With this awareness then manifested into various measures of action for the realization of a social system that is not gendered biased. There are several streams of feminism. First, liberal feminism. This feminist ideology was born from a liberal political theory that opposed the discrimination system for women in legislation. The orientation of liberal feminists, which is to create the same economic and political rights structure between men and women. Second, Marxist feminism. Feminist ideology has an orientation to eliminate the structure of classes in the system of social life. According to this feminist school, the backwardness of women is caused by social, political, and economic structures that are intervened by the capitalist system. In other words, women do not have the same access as men while living in a classy system. This is because the capitalist system causes women to no longer participate in the world of economic production which has an impact on the division of labor based on sex. Where men work in productive and economically valuable public spaces.

While women work in domestic spaces that are not productive and have no economic value. Third, radical feminism. This feminist ideology has an orientation to eliminate the patriarchal system radically, namely by severing relations with men in various aspects of life, including in the aspect of sexual relations. Fourth, socialist feminism. These feminists are more focused on efforts to self-awareness of women over their discriminatory positions. This feminist ideology encourages the creation of good work between women and men. Fifth, Islamic feminists. This feminist ideology views that discrimination against women is not only caused by a

${ }^{8}$ Siti Musdah Mulia, Keadilan Kesetaraan Gender Perspektif Islam (Cet. II; Jakarta: LKAJ, 2003), p. viii.

${ }^{9}$ Nasaruddin Umar, Argument Kesetaraan Gender dalam Perspektif al-Qur'an (Jakarta: Paramadina, 1999), 1st Edition, p. 35. 
gender-biased social system. But it is also caused by religious doctrines that are the result of interpretations of theological foundation, both the Qur'an and the Hadith. Therefore, according to feminist ideology, it is necessary to reinterpret the teachings or doctrines of religion by remembering gender equality which is the moral message in the Qur'an and Hadith. ${ }^{10}$

In the perspective of the Koran, there are at least several variables of the Koran that can indicate the existence of gender relations, including the following: (1) The similarity in the origin of human creation as explained in Qs. al-Nisa (4): 1; (2) Equation of duties as a leader on earth as explained in Qs. al-An'am (6): 165; (3) Equal rights in reciprocating acts of charity as explained in Qs. al-'Imran (3): 195; (4) The same potential to be a good servant before God as explained in Qs. alHujarat (49): 13; (5) The same pattern of interaction between men and women as explained in Qs al-Baqarah (2): 187; (6) Equal rights to get an education as explained in Qs. al-Mujadalah (58): 11; (7) Equal rights to achieve achievements as explained in Qs. al-Nahl (16): 97.

From the various verses of the Qur'anic verse above it can be understood that the Qur'an contains moral messages that uphold the principle of equality and gender justice between men and women. The principle of gender equality can be understood as a value or universal principle to be implemented in all aspects of human life. Where in the context of its application, the principle of gender equality can be manifested in gender mainstreaming efforts, namely strategies that are carried out rationally and systematically to realize gender justice in various sectors of life, both in the private (family) and public (community) areas social), as well as through programs that accommodate the experiences, aspirations, needs, and problems of women and men in the planning, implementation, monitoring, and evaluation of all programs in various fields of life. ${ }^{11}$

\section{Gender Mainstreaming In The Amina Wadud's Hermeneutic}

In general, hermeneutics can be understood as a theory or philosophy in understanding the meaning of texts. Not only that, but some call hermeneutics as a method used to understand the meaning or purpose of a human thought concept. Through the hermeneutic method can help us in understanding the true meaning desired by the text. Therefore, a serious and comprehensive interpretation or

${ }^{10}$ Athoillah Islamy, Diskursus Hak Perempuan Sebagai Wali dan Penghulu Nikah Di Indonesia (Ciputat: Cinta Buku Media, 2016), p. 25-26.

${ }^{11}$ https://id.wikipedia.org/wiki/Pengarusutamaan_gender Diakses 4 Oktober 2017. 
understanding effort is needed in finding the meaning contained in a text itself. ${ }^{12}$ In the hermeneutic methodology, there are at least three instruments used in interpreting the text. First, the study of texts, which includes the origin of the text, why the text was given meaning, and how the text was understood. Second, the mediator whose function is to explain the text, so that a text can be easily understood, includes thought patterns and assumptions about the audience. Third: the audience, which is the community to which the mediator aims to explain the text. $^{13}$

The spirit of the use of the hermeneutic method on the meaning of theological foundation text in the history of Muslims may be found from the existence of the Koran and Hadith. This is due to the need for Muslims to always understand the meaning contained in both (the Koran and Hadith) as a guide to the lives of Muslims. Moreover, after the death of the Prophet Muhammad, the authority of the sole interpreter of the meaning of the texts of the Qur'an and the Hadith no longer exists. Meanwhile, the condition of the times continues with its various problems and the number of Muslims is increasingly being spread to various parts of the world, insisting that the Qur'an and Hadith are not only understood by Arabs but are also beginning to be understood by non-Arabs ('ajam). These conditions encourage efforts to interpret the Qur'an and the Hadith is always carried out by Muslims in different socio-cultural conditions and with consideration of the progress of existing science and technology.

This was done as a form of effort to reevaluate the messages of meaning contained in the Qur'an and Hadith to be suitable for all times and places so that the Qur'an and Hadith can truly be a way of life and solutions to various problems. A life that continues to grow. ${ }^{14}$ From this, it follows that the variety of interpretations of the verses of the Qur'an and the different Hadith among Muslims is caused by at least two factors. First, the internal factors of the text are various aspects of the text itself. Second, the external factors of the text are various external aspects surrounding the text. Both internal and external factors often lead to a variety of different interpretations even though it is based on the same textual foundation, both the text of the Qur'an and the Hadith.

${ }^{12}$ M. Ilham Muchtar, “Analisis Konsep Hermeneutika dalam Tafsir al- Qur'an,” Hunafa: Jurnal Studia Islamika, Vol. 13, No. 1 Juni 2016: p. 69-71

${ }^{13}$ Agusni Yahya, "Pendekatan Hermeneutik dalam Pemahaman Hadis," Ar -Raniry: International Journal of Islamic Studies, Vol. 1, No.2 (2014), p. 372.

${ }^{14}$ Muhammad Amin, Kontribusi Tafsir kontemporer dalam Menjawab Persoalan Umat," Jurnal Substantia, Vol. 15, No.1 (2013), p. 2. 
To maintain and reflect the moral messages of the verses of the Qur'an so that they are always relevant and become values for real life. ${ }^{15}$ Wadud stated the need for continuous interpretation of the Koran. In this case, Wadud offered a method of al-Qur'an hermeneutics. According to Wadud, there is no single truth term in the results of interpretation (interpretation), so there is no certain interpretation term that is more or more correct than other interpretations. With this principle, it is expected to open an attitude for the commentator (interpreter) so as not to limit the breadth of the meaning of a verse. Through her book entitled Qur'an and Women, Amina Wadud also explained that there were no truly objective interpretations. In other words, every interpretation is greatly influenced by the subjectivity tendency of the exegete (interpreter). Nevertheless, Wadud argues that it is still often found in Muslim societies that groups or groups are found that assess the results of an interpretation as the final truth in revealing the meaning of the text of the verses of the Qur'an. Therefore, Wadud argues that the hermeneutic method is needed to understand the verses of the Koran especially to reveal the meaning of the Koran which cannot be revealed by classical commentators. ${ }^{16}$

Amina Wadud mapped the method of interpreting the Qur'an about the existence of women into three categories, namely traditional interpretations, reactive interpretations, and holistic interpretations. The explanation of the three categories of interpretation is as follows.

First, traditional interpretations, is interpretations that are atomistic, particular, juz'iyyat, namely the method of per verses interpretation and not thematic so that the discussion can be said to be partial. Without any effort to connect between ideas, syntactic structures, or similar themes, the reader does not find welstanschaung al-Qur'an. According to Wadud, this traditional model of interpretation has a pattern of exclusive tendencies and the majority are written by men. Therefore, the subjectivity and experience of men greatly affect the product of interpretation which should experience and perspectives of women also be included

${ }^{15}$ Civilization and social change in human life are always dynamic. While the existence of the texts of the Qur'an has stopped. Therefore, to maintain the synergy of the two, efforts to interpret the meaning of the text of the verses of the Qur'an must not stop. The presence of the Koran must be able to be presented and felt by the people. Therefore, the Qur'an must be historical. It is not an object in the ivory tower as a work of God that cannot be touched and cannot be understood. al-Qur'an must be grounded, which is to be part of the history of human civilization. Mudhofir Abdullah, "Kesejarahan al-Qur'an dan Hermeneutika," Journal of Qur'an and Hadith Studies, Vol. 3, No. 1, (2014), p. 74.

${ }^{16}$ Amina Wadud, Qur'an and Woman Rereading the Sacred Text from a Woman's Perspective (New York: Oxford University Press, 1999), p. 1. 
in the consideration of the interpretation process so as not to produce interpretive products that are discriminatory against the existence of women.

Second, reactive interpretation is interpretation in the form of reactions of modern Islamic scholars to the phenomenon of discrimination against the existence of women who are ascribed to the results of the interpretation of the Qur'an. The method used in this interpretation is usually derived from feminist and rationalist ideas without a comprehensive analvsis of the verses concerned. According to Wadud, although the idea of modern Islamic scholars is liberation, its relevance to the theological foundation in Islam, that is, the Qur'an can be said to be even less precise.

Third, holistic interpretation is interpretations that use comprehensive interpretation methods and also revive them with a variety of contextual issues that exist when the text is interpreted, such as social, political, and also women's issues that are happening.

Of the three categories of interpretation above, Wadud positioned himself in the third category (holistic interpretation), which is a comprehensive interpretation method. The holistic approach in contemporary Islamic studies is something that receives great attention in all cross-disciplines not only in the context of interpretation. This was done to find a comprehensive study of Islamic studies. ${ }^{17}$

Through his book titled Quran and Women, Wadud showed how his interpretation method was in re-understanding the verses of the Qur'an, especially interpretations that explain the existence of women. According to Wadud, the interpretation of the existing classical model has produced a gender-biased interpretation, that is, an interpretation that discriminates against the existence of women. In this case, Wadud offers a new method of interpretation which is named Tauhid Interpretation. According to Wadud, by using the method of interpretation of monotheism can produce a product of interpretation that is different from existing interpretations. According to Wadud, the hermeneutic method of the Qur'an offered is a method of interpretation which in its technical application aims to find the meaning of a text or verse by considering three aspects.

First, the context at which the text was written and interpreted. In this case, Muslim Abdul Kadir explained that the product of one's thought towards religious practices originating from the revelation of God is a product of a thought that is influenced by the episteme in which he lives. ${ }^{18}$ In this case, Said Agil Husin Al-

\footnotetext{
${ }^{17}$ Tahtimatur Rizkiyah, Athoillah Islamy, Pendidikan Holistik Dalam Pendidikan Islam (Ciputat: Cinta Buku Media, 2016), p. 11-15.

${ }^{18}$ Muslim Abdul Kadir, Ilmu Islam Terapan: Menggagas Paradigma dalam Agama Islam (Yogyakarta: Pustaka Pelajar, 2003), 1st Edition, p. 142.
} 
Munawar also explained that in the context of Islamic law there are at least two categories of tasyri '(Islamic legal legislation). First, tasyri 'celestial. The authority of legal legitimacy in tasyri'ini is directly from God. Therefore, tasyri' is absolute. Second, tasyri' wadh' $i$. This legal legitimacy authority is based on the results of human ijtihad (mujtahid). Therefore, tasyri' is influenced by the ability, background, and sociological conditions of the different mujtahids, so that tasyri' is relative (relative) and dynamic following existing conditions. Therefore, it becomes a necessity if the conclusion of plural Islamic law is not singular although it is based on the same theological text (al-Qur'an and Hadith). ${ }^{19}$

Second, grammatical text. In this case, Nasaruddin Umar argues that gender aspects in Arabic can be identified by the use of dhomir (pronouns of people) and gender specialization. Further information is as follows. First, the use of dhomir follows the general Arabic rule that the mention of the bible (commandment) in the verb which stores male dhomir is also binding on women unless there are specific indicators directed at men. Another case is the mention of dhomir for women which is only addressed to women. Secondly, there are nouns (isim) between men and women, such as Muslim (male) and Muslimatun (female). The use of nouns intended for both (male and female) is sometimes sufficient to use the male identity (mudhakar). Another case is a noun intended specifically for women. Furthermore, in this case, Nasaruddin also emphasized that not only in Arabic but also in other languages, especially those included in the Semitic language family, such as Hebrew, Syrian, and Persian, even other languages such as languages English and various other European languages also show a gender bias, namely the tendency of masculine traits in language expression. ${ }^{20}$

Third, weltansanschaung (world view). According to Wadud, every verse that is interpreted must be analyzed according to its revealing context (asbab al-nuzul). Then the grammatical aspects of the language used in the verses of the Qur'an. Furthermore, it is relevant to the context of the existing world view. ${ }^{21}$ In this case, the Wadud method can also be said to use the Qur'anic interpretation method conceived by Fazlur Rahman, known as The Double Movement Theory. Where is the first move which is an effort to understand the historical situation and

${ }^{19}$ Said Agil Husin Al-Munawar, sebuah pengantar dalam buku Diskursus Hak Perempuan Sebagai Wali dan Penghulu Nikah di Indonesia Oleh Athoillah Islamy, iii.

${ }^{20}$ Nasaruddin Umar, Argument Kesetaraan Gender dalam Perspektif al-Qur'an, p. 194-208.

${ }^{21}$ Amina Wadud, Qur'an and Woman Rereading the Sacred Text from a Woman's Perspective, $\mathrm{p}$. 
problems during the revelation to find the legal illat (legal ratio) in a law. Next is the second movement which is an attempt to generalize and systematize the general principles of the first movement in the context of today's reality. ${ }^{22}$

\section{Application of Amina Wadud's Hermeneutic (al-Quran) About Gender Relations in the Family}

In the context of liberalism, Islamic legal thinking, in general, cannot be separated from four issues, including the issue of democracy, ${ }^{23}$ Human Rights, pluralism, and gender. Those related to gender issues are based on the awareness and understanding of the discriminatory factors of women which are not only caused by a social system that is gender-biased but also the gender-biased interpretation of the normative basis of Islamic theologians (Al-Quran or Hadith). It is this awareness that then drives the reinterpretation of existing Islamic legal doctrines or products. ${ }^{24}$ This is what has then encouraged contemporary commentators to offer methods of interpretation that bring a spirit of justice and gender equality. Among the existing figures, namely Amina Wadud.

Wadud's method of reinterpreting the existence of women from a theological basis can be said to be in line with some other contemporary figures, such as Khoiruddin Nasution who argues that based on several verses in the Koran it can be said that the Koran requires an equal gender relations pattern between men and women. Where no party is superior to others and vice versa no one is more inferior than others. ${ }^{25}$ Qasim Amin as quoted by Nasarudddin Umar also stated that the Qur'an upholds the position of women in all aspects of life. ${ }^{26}$ Furthermore, Husein Muhammad also explained that the verses of the Qur'an must be understood contextually and proportionally, namely by looking at the

${ }^{22}$ M. Samsul Ma'arif, "Epistemologi Fazlur Rahman Dalam Memahami Al-Qur'an dan Hadis." Manthiq, Vol. 1, No. 1 (2016), p. 9.

${ }^{23}$ One of the central issues in the renewal of fiqh siyasa thinking, is the effort to find the validity of a democratic political system in the perspective of Islamic law. As one of the perspective offers, Yusuf al-Qaradhawi states that in the context of the modern nation state, democratic political systems originating from Western political civilization can still have legitimacy in Islamic law as long as the objective values of Islamic law (maqasid shariah) can be implemented in the system the politics. Athoillah Islamy, Sansan Ziaul Haq, Democratic Political System In The Perspective of Maqasid Sharia: Analytical Study of Yusuf Al-Qaradawi's Thought," Al-Imarah Jurnal Pemerintahan dan Politik Islam, Vol.5, no.1 (2020): p. 55.

${ }^{24}$ Athoillah Islamy, "Eksistensi Hukum Keluarga Islam di Indonesia dalam Kontestasi Politik Hukum dan Liberalisme Pemikiran Islam," Al-Istinbath: Jurnal Hukum Islam, Vol.4, No.2 (2019): p. 168.

${ }^{25}$ Khoiruddin Nasution, Hukum Perdata (keluarga) Islam Indonesia Dan Perbandingan Hukum Perkawinan Di Dunia Muslim: Studi Sejarah, Metode, Pembaharuan Materi dan Status Perempuan Dalam Perundang-Undangan Perkawinan Muslim (Cet. I; Yogyakarta: Academia Tazzafa, 2009), p. 257.

${ }^{26}$ Nasaruddin Umar, Argument Kesetaraan Gender dalam Perspektif al-Qur'an, p. 295 
background of the verses (asbab al-nuzul) by comparing and correlating them with the conditions of the times. It is intended to find the moral message contained in these verses, so they are not stuck and caught up in the understanding of the textual text. ${ }^{27} \mathrm{n}$ this case, Nasaruddin Umar argues that there are several functions or uses of understanding Asbab al-Nuzul. First, to find out the wisdom of establishing law. Second, to help in the explanation of a verse. Third, to know the generality and specificity of the validity of the verse and also in what way the verse is applied or intended. But in this case, it should be noted that the verses of al-Qur'an that have asbab al-nuzul are fewer than those who do not have them. ${ }^{28}$

According to Wadud, the interpretation methods he offered differed greatly from the classical (traditional) interpretation methods. Wadud stated that existing traditional interpretations could not reflect moral ideas or messages from the verses of the Qur'an. Not only that, but most interpretations of the results of interpretation have also traditionally been dominated by mufassir who are male. Where the factors of inclination, perceptions, visions, and personal experiences of the male commentator greatly influence the results of his interpretation. In this case, Wadud argues that two aspects must be understood seriously in interpretation, namely language and prior text. The prior text referred to here, namely the socio-cultural conditions (context) when the text is read or interpreted. According to Wadud, the prior text is often a perspective in interpretation that can lead to subjectivity or relativity in interpretation. In his monotheistic interpretation method, Wadud distinguishes between the dimensions of the moral message of verses of the Qur'an which are universal and the dimensions of verses of the Qur'an that are local temporal. Besides, Wadud also emphasized the principles of text language to be relevant to gender issues. This was done because Wadud saw that some of the results of traditional interpretations often represented verses that were neutral from the gender category to gender verses. In connection with the disregard of the verses of the Koran about gender, Wadud took a stand by not giving priority to certain sexes. This was done to adjust to universal Qur'anic guidance. According to Wadud, the moral message contained in the verses of the Qur'an does not indicate the dominance of existence between the sexes, both male and female. Where both have the same potential in carrying out their duties as servants of God and creatures in the world. ${ }^{29}$

\footnotetext{
${ }^{27}$ Husein Muhammmad, Fikih Perempuan: Refleksi Kiai atas Wacana Agama dan Gender (Yogyakarta: LKis, 2001), 1st Edition, p. 15-19.

${ }^{28}$ Nasaruddin Umar, Teologi Jender Antara Mitos dan Teks Kitab Suci (Jakarta: Pustaka Cicero, 2003), 1st Edition, p. 59-63.

${ }^{29}$ Amina Wadud, Qur'an and Woman Rereading the Sacred Text from a Woman's Perspective, $\mathrm{p}$. 
Wadud argues that the culture of Muslim societies that places men in the priority position of women in all sectors of life is contrary to the universal purpose of the Qur'an. Wadud stated that patriarchal-style interpretation products had placed women as second-class creatures. One example of the theme of interpretation is using the interpretation methodology in the perspective of Amina Wadud, which is related to the interpretation of the Qur'an al-Nisa 'verse 34 concerning leadership in the domestic sphere as follows:

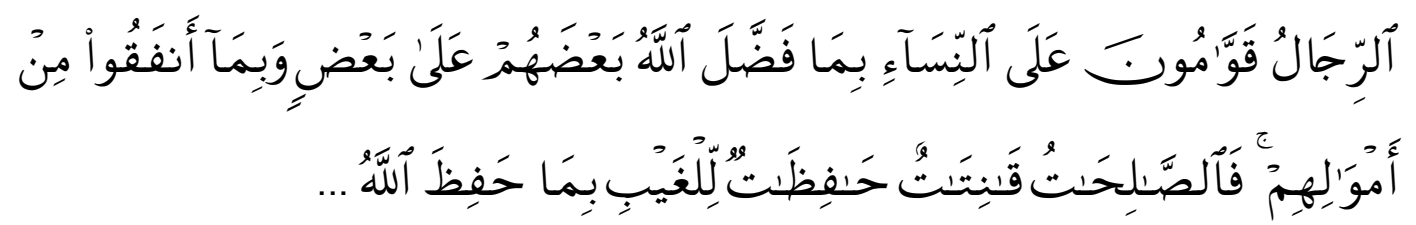

Meaning: Men are leaders for women, because Allah has increased their portion (men) over another part (women), and because they (men) have spent part of their property. Therefore, godly women, who are obedient to God, take care of themselves when their husbands are gone, because God has looked after (them).

When it is understood or interpreted literally (textually), the explanation of the above verse looks discriminatory against the existence of a woman (wife). Therefore, Wadud tried to reinterpret it hermeneutically. According to Wadud, the interpretation is different from the various existing interpretations as contained in the commentary books. There are several steps taken by Wadud in understanding the verse.

First, related to the meaning of the word "qawwam". For Wadud, the meaning or understanding of the word qawwam is not only limited to the context of marital relations. But in a broader context that is the society in general. Wadud also believes that the meaning of the word qawwam does not automatically indicate the superiority of men over women. Wadud added that it does not stop at the editor of the word qawwam, in that verse, there is also the editor of the verse that reads "bi maa faddhalahu ba'dhohum ala ba'dhin," For Wadud, the editorial of the verse shows the contextual meaning in the interaction between men and women that is, under certain conditions men can have more capacity to be responsible for women both in domestic and family areas. But on the contrary, in certain conditions also women can have more capabilities than men, so women are more worthy or can be leaders of men.

Second, the historical context approach when the verse was revealed. In this case, Wadud understands the context in which a text (al-Qur'an verse) is interpreted. This is called the prior text. However, before understanding the prior text, Wadud tried to understand the context conditions when the text of the verse was revealed. According to Wadud that the cultural condition of the Arabian 
Peninsula community at the time of the verse came down was patriarchal culture. The patriarchal culture in question, that is, a culture structured over domination and sub-alliance. Where patriarchal culture upholds the existence of men in all lines of life. Therefore, it becomes necessary if the existence of men has a position of power and superiority in leadership, both in the context of family and society. From the conclusion of this understanding, Wadud argues that the moral message that is universal in the verse is the existence of the same role between women and men related to rights and responsibilities, namely there is no term superiority and inferiority between men and women. However, it should be understood that the implementation of these rights and responsibilities is contextual following existing conditions. In this case, Wadud better understood it as a cooperative relationship (partners) between men and women, both in the context of family life and social society. In other words, Wadud called it a functionalist relationship. The functional relationship in question is the cooperative relationship over the distribution of rights and responsibilities of each man and woman based on his potential not based on things that are given (natural) as well as gender. After finding a moral message that is universal in the verse, namely the partner or functionalist relationship between men and women then contextualized with the context when the verse is interpreted. ${ }^{30}$ Thus it can be understood that the use of the Hermetical method offered by Wadud can produce a contextual interpretation of the verse following the spirit of existing gender relations.

\section{CONCLUSION}

From the description of the explanation of the previous material, it can be concluded that the hermeneutical methodology of the Koran in the perspective of Amina Wadud is more patterned on gender mainstreaming, namely a hermeneutical method which has an orientation to contextualize the moral message in the verses of the Koran, especially related to gender relations patterns in the context of the times. In its application, the al-Qur'an hermeneutic method offered by Wadud considers three aspects as the basis for the interpretation of a text (verse). First, the context at which the text was written and interpreted. based on the same theological (al-Qur'an and Hadith) texts. Second, the grammatical text, namely the form of the text of the Koran in conveying its moral message. Third, weltansanschaung or existing world view. By considering these three aspects, Wadud tried to reinterpret a theological basis (verses of the Qur'an) related to the pattern of gender relations that have been interpreted by many classical

\footnotetext{
${ }^{30}$ Amina Wadud, Qur'an and Woman Rereading the Sacred Text from a Woman's Perspective, $\mathrm{p}$.
} 
commentators. This was done because Wadud saw the products of classical interpretations that discussed the concept of gender relations in Islamic law products that are gender-biased, namely discriminatory to the existence of women because of gender-biased interpretation methods.

Then in the application of Amina Wadud's hermeneutic method in understanding the verses of gender relations in the family, it was concluded that the cooperative relationship between men and women in family life is a functionalist relationship. The functional relationship in question is the cooperative relationship over the distribution of rights and responsibilities of each man and woman based on his potential not based on things that are given (natural) as well as gender. After finding a universal moral message in the verse, namely the partner or functionalist relationship between men and women is then contextualized with the context when the verse is interpreted.

\section{REFERENCES}

Amin, Muhammad, Kontribusi Tafsir kontemporer dalam Menjawab Persoalan Umat," Jurnal Substantia, Vol. 15, No.1, 2013.

Abdullah, Mudhofir, "Kesejarahan al-Qur'an dan Hermeneutika," Journal of Qur'an and Hadith Studies, Vol. 3, No. 1, 2014.

Abdul Kadir, Muslim, Ilmu Islam Terapan: Menggagas Paradigma dalam Agama Islam, Yogyakarta: Pustaka Pelajar, 2003.

Echols, Jhon M. Hasan Shadily, Kamus Inggris Indonesia, Jakarta: Gramedia, 1999.

Islamy, Athoillah, Gender Mainstreaming dalam al-Qur'an dan Hadis serta Relevansinya Terhadap Epistemologi Hukum Islam,” Jurnal Hukum Islam, Vol.15, No.1(2017)

Islamy, Athoillah. 2019. "Eksistensi Hukum Keluarga Islam di Indonesia dalam Kontestasi Politik Hukum dan Liberalisme Pemikiran Islam," Al-Istinbath: Jurnal Hukum Islam, Vol. 4, No.2.

Islamy, Athoillah, Sansan Ziaul Haq, 2020. "Democratic Political System In The Perspective of Maqasid Sharia: Analytical Study of Yusuf Al-Qaradawi's Thought," Al-Imarah: Jurnal Pemerintahan dan Politik Islam, Vol.5, no.1.

Islamy, Athoillah, 2016.Diskursus Hak Perempuan Sebagi Wali dan Penghulu Nikah di Indonesia, Ciputat: Cinta Buku Media

Muchtar, M. Ilham, "Analisis Konsep Hermeneutika dalam Tafsir al- Qur'an,” Hunafa: Jurnal Studia Islamika, Vol. 13, No. 1,2016. 
Ma'arif, M. Samsul "Epistemologi Fazlur Rahman Dalam Memahami Al-Qur'an dan Hadis.” Manthiq, Vol. 1, No. 1, 2016.

Mutrofin, "Kesetaraan Gender dalam Pandangan Amina Wadud dan Riffat Hassan, "Teosofi, Vol.3, No. 1, 2013.

Muhammmad, Husein, Fikih Perempuan: Refleksi Kiai atas Wacana Agama dan Gender, Yogyakarta: LKis, 2001.

Mulia, Siti Musdah, Keadilan Kesetaraan Gender Perspektif Islam, Jakarta: LKAJ, 2003.

Nasution, Khoiruddin, Hukum Perdata (keluarga) Islam Indonesia Dan Perbandingan Hukum Perkawinan Di Dunia Muslim: Studi Sejarah, Metode, Pembaharuan Materi dan Status Perempuan Dalam Perundang- Undangan Perkawinan Muslim, Yogyakarta: Academia Tazzafa, 2009.

Ramli, Mohd Anuar, “ Gender Analysis In Islamic Jurisprudence,” Journal Of Fiqh, No. 9; 2012.

Rizkiyah, Tahtimatur, Athoillah Islamy Pendidikan Holistik Dalam Pendidikan Islam, Ciputat: Cinta Buku Media, 2016.

Rusli, "Isu-Isu Gender Dalam Bingkai Metodologi Studi Islam,” Musawa, Vol.4 No.1, 2012.

Setiawan, Asep, "Hermeneutika al-Qur'an Mazhab Yogya," Jurnal Studi Ilmu-Ilmu alQur'an dan Hadis, Vol. 17, No. 1(2016)

Umar, Nasaruddin, Argument Kesetaraan Gender dalam Perspektif al-Qur'an, Jakarta: Paramadina, 1999.

Umar, Nasaruddin, Teologi Jender Antara Mitos dan Teks Kitab Suci, Jakarta: Pustaka Cicero, 2003.

Wadud, Amina, Qur'an and Woman Rereading the Sacred Text from a Woman's Perspective, New York: Oxford University Press, 1999.

Yahya, Agusni, "Pendekatan Hermeneutik dalam Pemahaman Hadis," Ar -Raniry: International Journal of Islamic Studies, Vol. 1, No.2, 2014. 